UDC: 576.533

\title{
Morphological characteristics of mesenchymal stem cells from Wharton jelly, cultuivated under physiological oxygen tensions, in various gas mixtures
}

\author{
N. S. Shuvalova, V. A. Kordium \\ ${ }^{1}$ State Institute of Genetic and Regenerative Medicine, NAMS of Ukraine \\ 67, Vyshhorodska Str., Kyiv, Ukraine, 04114 \\ 2 Institute of Molecular Biology and Genetics, NAS of Ukraine \\ 150, Akademika Zabolotnoho Str., Kyiv, Ukraine, 03680 \\ riyena@yandex.ua
}

\begin{abstract}
Aim. Cultivation of mesenchymal stem cells (MSC) under physiological oxygen tensions has beneficial effect on their properties. The aim of the present work was to examine the effects of mild hypoxic conditions on the morphologic behavior of MSC from human Wharton jelly (WJ-MSC). Methods. WJ-MSC were obtained by an explant method and cultured in gas mixtures containing $3 \% \mathrm{O}_{2}, 4 \% \mathrm{CO}_{2}$ and $93 \%$ nitrogen or argon. At each passage the cultures were fixed and stained with hematoxylin and eosin. The morphometric analysis of microphotographs was performed, and the nuclear-cytoplasmic ratio (NCR) and the width/length ratio were calculated. Results. The difference in NCR and the width/length ratio was detected between WJ-MSC cultures at various passages and between the cultures at the same passage, maintained in different gas mixtures. The highest level of morphological homogeneity was observed at passage 2 . At passage 3 , the cells with senescent morphology can be observed. The degree of heterogeneity in populations cultured at $3 \% \mathrm{O}_{2}$ appeared to be lower than under standard conditions. WJ-MSC, cultured in the nitrogen-based gas mixture were the most homogeneous. Conclusions. The changes in WJ-MSC culture morphology were observed at early passages. The level of morphological heterogeneity varied with the cultivation time. The conditions of mild hypoxia had a positive impact on the cultured cells.
\end{abstract}

K e y w or d s: mesenchymal stem cells, Wharton jelly, morphology, hypoxia, argon

Mesenchymal stem cells (MSC), a population of multipotent somatic stem cells, are viewed as an attractive tool for cellular therapy. MSC, derived from birth-associated tissues, especially from Wharton's jelly (WJ-MSC), are of particular interest. The use of WJ-MSC for therapeutic application does not face ethical concerns. Besides, it was shown, that in comparison with MSC from other sources, WJ-MSC possess exceptional properties, such as differentiation potential [1] and paracrine activity [2], and show unique immune modulatory effects [3].
Due to low frequency of MSC original occurrence in tissues, their ex vivo expansion is required for use in both research and clinical practice. The cultivation protocols, described in different reports vary in the choice of cultivation media, growth substrates, and planting density. Depending on these conditions, the proliferation rates of cultures may differ even in the cultures obtained from the same source [4].

Irrespective of the cultivation protocol used, the cells morphologic behavior is one of the most simple and available, yet informative parameters to be monitored. A set of standard MSC identification criteria

(C) 2016 N. S. Shuvalova et al.; Published by the Institute of Molecular Biology and Genetics, NAS of Ukraine on behalf of Biopolymers and Cell. This is an Open Access article distributed under the terms of the Creative Commons Attribution License (http://creativecommons.org/licenses/by/4.0/), which permits unrestricted reuse, distribution, and reproduction in any medium, provided the original work is properly cited 
includes the morphological characteristics of culture, stating that fibroblastoid, spindle-shaped morphology is typical for MSC, regardless of their origin [5]. Thus, the observed morphological abnormalities can indicate destructive changes in the culture.

It was also shown, that examination of the MSC morphology allows evaluating the expansion capacity of cultures. Many works describe the correlation of cells size and shape with their proliferative potential $[6,7]$. Normally, MSC are characterized by fibroblastoid morphology and spindle-like shape. Some works demonstrated that MSC of smaller sizes and slender spindle-like shape have a higher proliferative capacity [8]. In contrast, the appearance of cells with altered morphology, for instance, the ones having irregular shape, can be an indication of the beginning of destructive process in the culture. Many works state that the enlarged cell of flattened shape is typical for the senescent culture [9, 10]. Thus, monitoring the morphology allows estimating the preservation of important culture properties in time to abandon the populations with abnormalities.

In vivo, the major role in preservation of the MSC properties is played by their natural localization site niche. Niches include surrounding cells, extracellular matrix, and secreted soluble signal molecules, acting as informational signals $[11,12]$. The crucial external factor regulating the functioning of MSC niche is the concentration of oxygen that was shown to be lower than in other sites of the tissue [13].

Considering that the environment in culture conditions differs from the physiological ones drastically, ex vivo multiplication of MSC is associated with the risk of losing their therapeutically relevant features [14]. During the cultivation period, a progressive accumulation of damages can be observed in the cell culture $[15,16]$. According to the numerous studies, an oxidative stress is the main reason of the cell premature senescence [17]. Thus, the ambient oxygen concentration in $\mathrm{CO}_{2}$ incubator, which is significantly higher, than physiological one, can be thought as one of the major damaging factors, affecting MSC in culture. In this context, MSC cultivation under physiological oxygen tensions, or so- called conditions of mild hypoxia (ranging from $1.5 \%$ to $8 \%$ ), resembling the ones in tissues, is considered to be a perspective approach $[18,19]$.

Numerous works have demonstrated that MSC maintenance under reduced oxygen tensions has a positive impact on many stem cell properties: preservation of proliferative and differentiation potentials, migratory capacity, etc. The aim of the present work was to estimate the effect of WJ-MSC cultivation under physiological oxygen tensions on the morphological behavior of MSC cultures.

\section{Materials and Methods}

MSC isolation. MSC were isolated from human Wharton jelly (WJ) using the explants method, as described in our previous work [20]. Umbilical cords (UC) were collected from three healthy donors (3940 weeks of gestation, normal delivery), after obtaining informed consent. The UC fragment $(5-10 \mathrm{~cm})$ was washed twice with PBS, the blood vessels were removed. WJ was chopped, and the fragments were placed in the cultural flacks, $75 \mathrm{~cm}^{2}$, with complete expansion medium (DMEM with low glucose (PAA Austria) supplemented with $10 \%$ fetal bovine serum (PAA, Austria), glutamine $2 \mathrm{mM}$ (PAA, Austria), penicillin $100 \mathrm{U} / \mathrm{ml}$ (Arterium, Ukraine), streptomycin $100 \mu \mathrm{g} / \mathrm{ml}$ (Arterium, Ukraine). The attached cells were observed on the $7-10^{\text {th }}$ day. After approx. 2 weeks, on reaching the size and 70-80\% confluence, the clones were passed with trypsin-EDTA ( $0.1 \%$ trypsin and $0.02 \%$ EDTA) solution.

At passage 1 the surface marker proteins CD90, CD73, CD105 expression was estimated (over $85 \%$ positive), using flow cytometry (BD FACS Aria) with fluorescein- and rhodamine-conjugated antibodies (UsBiological, USA).

Starting from the passage 1, WJ-MSC were replated (as described above) and expanded for $5 \mathrm{sub}$ sequent passages (for 7 days at each passage) in complete growth media. All cultures were replated simultaneously and at the same cell density, as described in our previous work [20].

Gas mixtures preparation. The experimental groups of WJ-MSC cultures, starting from pas- 
sage 1 , were maintained in the gas mixtures based on nitrogen ( $3 \%$ of oxygen, $4 \%$ of carbon dioxide, $93 \%$ of nitrogen) and argon (3\% of oxygen, $4 \%$ of carbon dioxide, $93 \%$ of argon). The cultures maintained in $\mathrm{CO}_{2}$ incubator (4\% carbon dioxide, ambient oxygen concentration $-20 \%$ ) served as controls in all experiments. The cultures from all groups were maintained at $37^{\circ} \mathrm{C}$ in a humidified atmosphere.

For the present study, a system for preparation of nitrogen and argon-based gas mixtures was developed. The system consists of three gas cylinders with carbon dioxide, nitrogen and argon, air pump, gas mixing device and the terminal container. The terminal container is connected to gas analyzer PGA 200 (JSC "Electronstandart-pribor", Russian Federation). Through monitoring the data of the gas analyzer on the concentration of carbon dioxide and oxygen in the gas mixture, with reductors on the mixing device and air pump, it is possible to regulate the speed of gas supply from cylinders and thus prepare the gas mixture of required concentration. From the terminal container through a short tube the prepared mixture is supplied to the polyethylene bags with a hermetic clasp.

WJ-MSC cultivation in gas mixtures. The flacks and Petri dishes with WJ-MSC cultures were placed into the polyethylene bags with hermetic clasp (1.5 1). The bags were washed twice with the gas mixture, containing $4 \%$ of $\mathrm{CO}_{2}$ and $96 \%$ of nitrogen or argon (depending on the group), after that were filled with the gas mixture used for cultivation (see above), and set in the vacuum containers (Scarlet). The containers with bags were kept incubated at $37{ }^{\circ} \mathrm{C}$. The percentage "liquid media/gas" for normal gas exchange must be 1:100 [21], the volume of gas mixture must be not less than 11 [20].

Morphology analysis. Morphology analysis was performed at passages 1 to 3. After the first replating, at each passage, some of the expanded MSC were separated and seeded on plastic Petri dishes $(\mathrm{d}=35 \mathrm{~mm})$, $50 \times 10^{4}$ per dish and cultured for 3 days. After cultivation, dishes were fixed with paraformaldehyde vapours for $7 \mathrm{~min}$ at room temperature, and stained with hematoxylin and eosin. Microscopy of the cultures was performed with the microscope Leica DMIL. Images were taken from different areas of each dish, by camera Cannon PowerShot 640A, x100, zoom x1,4.

Using Image $\mathrm{J}$ software, the following parameters were measured on microphotographs: cell area, nuclear area, cell width (in the nuclear area) and length (the length of the line crossing three points: peak of "spindle pole" №1, centre of nucleus, peak of "spindle pole” №2). The values were assessed for 100 cells from each group on 3 images. For each cell analyzed, nuclear-cytoplasmic ratio (NCR) and the "width" length" ratio were calculated in Excel. The last parameter reflects, whether the cell's shape resembles a "spindle-like" one. In present study, the ratio value 0.3 appeared to be optimal to characterize the "classic" spindle-like shape.

The NCR was calculated as: NCR = An/Ac, An nuclear area, Ac - cell area. The "width $\backslash$ length" ratio was estimated by dividing the value of cell width by cell length.

Statistics. Three independent experiments were performed. Coefficient of variation (CV) was calculated as the ratio of the standard deviation to the mean. Statistical significance was determined using Mann-Whitney U-test at $\mathrm{P}<0.05$.

\section{Results and discussion}

In the present study, at passages 1-3, the morphology of fixed stained WJ-MSC cultures was analyzed. The areas of nuclei and cell, as well as width and length were estimated on the culture images. The NCR, "width $\backslash$ length" ratio for each measured cell, and $\mathrm{CV}$ for experimental groups were calculated. The analysis showed the change in morphological behaviour of the cultures from the same cultivation conditions during the time of in vitro cultivation, as well as the difference between the groups, cultivated in different gas mixtures (Fig. 1).

Figure 1 shows the microphotographs of WJ-MSC cultures at passages 1-3, cultivated under standard conditions in $\mathrm{CO}_{2}$-incubator, and in two different hypoxic gas mixtures, containing $3 \%$ oxygen, based on argon or nitrogen. Visually, at the first two passages, the morphology in all groups appeared to be similar. However, slight differences could be noticed. The 

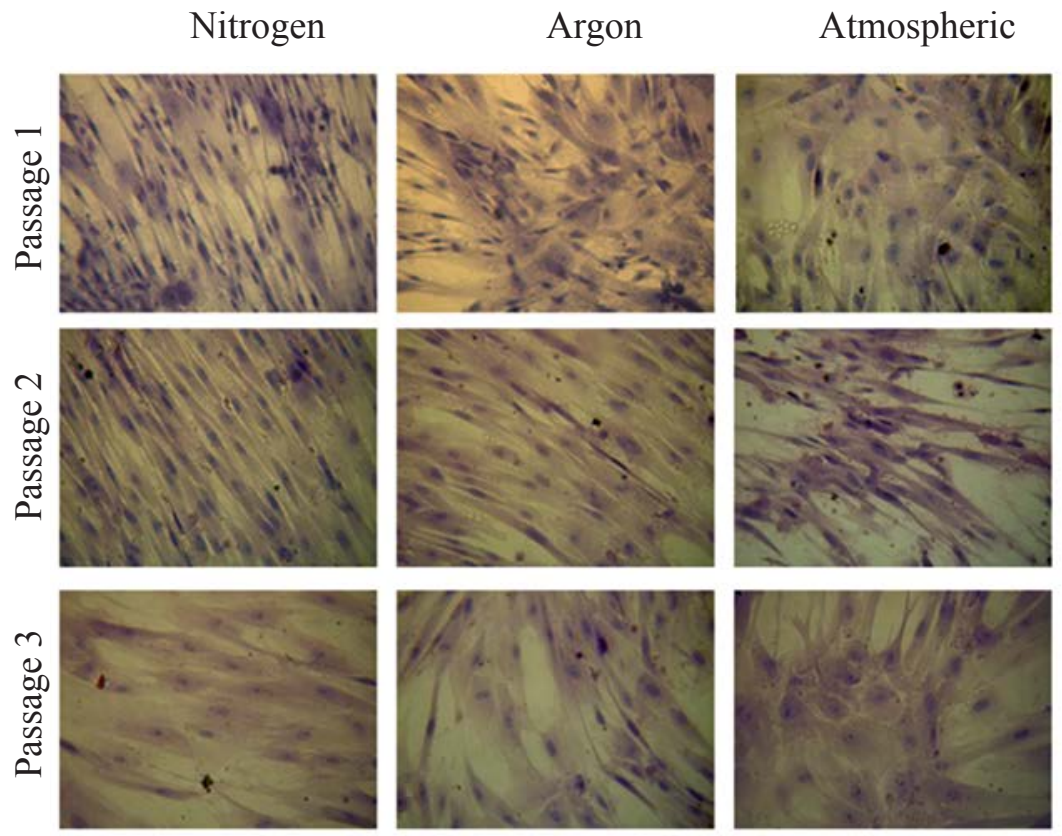

Fig. 1. Morphology of WJ-MSC cultures at passage 1 to 3 , after three days of cultivation, stained with hematoxylin and eosin. "Nitrogen" - nitrogen-based gas mixture (3\% oxygen, $4 \%$ carbon dioxide, $93 \%$ nitrogen), "argon" - argon-based gas mixture (3\% oxygen, $4 \%$ carbon dioxide, $93 \%$ argon), "atmospheric" - $\mathrm{CO}_{2}$ incubator conditions, x100, camera zoom x1.4.

passage 3 in all groups was characterized by appearance of the cells with altered morphology. These cells were larger in size and had a so-called flattened shape, with poorly discernible "spindle's" peaks and relatively high "width/length" ratio. Though no marked production of vacuoles and granules (typical for senescent cells) was observed in the cytoplasm, such phenotype can be considered a senescent one according to literature. The control group, maintained under atmospheric oxygen concentration, contained the largest number of altered cells.

The scatter plots (Fig. 2) demonstrate the NCR and "width/length" ratio in populations, each point showing the value for single cell. Considering the data, two conclusions can be made. First, despite the visual similarity, the evaluation of morphometric parameters revealed pronounced differences in the level of heterogeneity between MSC, cultured in the same gas mixture at different passages, and between populations at the same passage, maintained in different gas mixtures. The highest level of morphological homogeneity could be observed at the passage 2 .

Next, the influence of the conditions of mild hypoxia concentrations was demonstrated. Concerning the morphology, MSC cultures from both gas mix- tures were obviously less heterogeneous, than the ones under standard $\mathrm{CO}_{2}$-incubator conditions. Fig 1 and 2 show that, at the passage 3 , the number of senescent cells under $3 \% \mathrm{O}_{2}$ was significantly lower comparing to ambient oxygen concentration. WJMSC populations, cultured in nitrogen-based gas mixture were the most homogenous ones. MSC cultivated in $\mathrm{CO}_{2}$-incubator appeared to have the highest level of diversity, which was indicated by the largest number of cells with altered shape. It needs to be further investigated whether this effect was observed due to the selection of rapidly-growing subpopulation, under physiological oxygen tension, or due to the prevention of early senescence in culture.

Fig. 3 shows the coefficients of variation, calculated independently for NCR and "wll" ratios, to compare the parameter variabilities in different groups. The highest level of homogeneity, of both shape and NCR values, was observed in the cultures from hypoxic mixtures, at the passage 2 . WJ-MSC from nitrogen-based mixture appeared to be the most homogenous ones. It should be noted, that, despite the same $\mathrm{O}_{2}$ concentration, the difference between the effects of mixtures was obvious. The mechanisms, that underlie this effect, needs to be investigated further. 

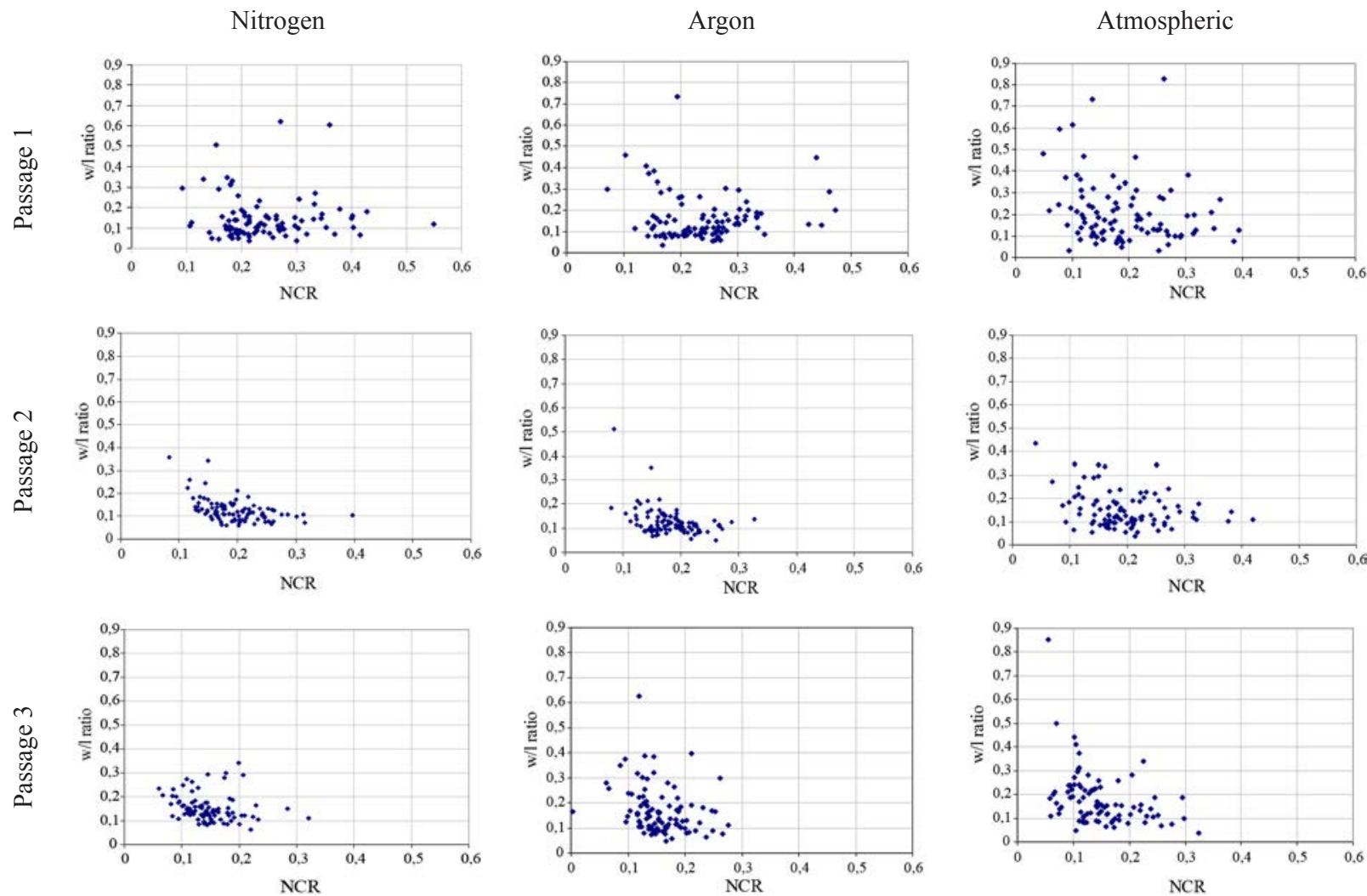

Fig. 2. Morphology analysis. NCR and "width/length" ratio. MSC cultures at passages 1-3, "Nitrogen" - nitrogen-based gas mixture (3\% oxygen, $4 \%$ carbon dioxide, $93 \%$ nitrogen), "argon" - argon-based gas mixture (3\% oxygen, $4 \%$ carbon dioxide, $93 \%$ argon), "atmospheric" - CO2 incubator conditions

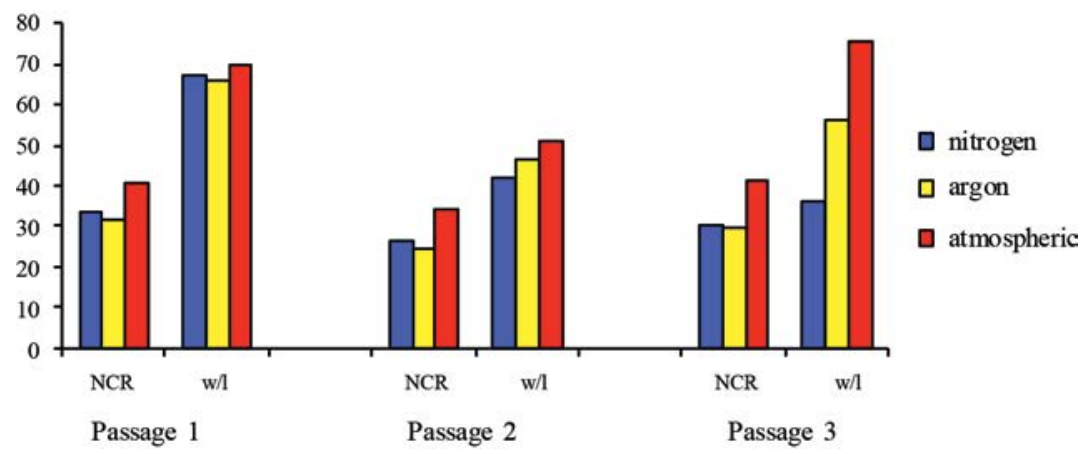

Fig. 3. Coefficients of variation, NCR and "width/length" ratio. The data are expressed as a percentage.

Cell morphology can be viewed as an indication of cell's internal physiological processes, for instance, status of cytoskeleton. In this context, it can be considered even as some kind of regulatory fac- tor. There are studies demonstrating an influence of the plating density (and the way these conditions modulate a cell shape) on the proliferative capacity and commitment in cultures. According to these 
works, the shape adopted by MSC, depending on the substrate properties, can even act as a signal for the differentiation itself $[22,23]$.

Recent studies have revealed that the cultivation conditions, for example, the media chosen, affect the morphology and dynamics of its change [4]. This is an important fact to be noted, because MSC from the same tissue source can be visually different, when exposed to different cultivation conditions. Longterm cultivation can increase the level of such diversity. The morphology analysis is one of the most informative criteria to examine the peculiarities of these processes. Combined with other parameters its results can give the full picture of the cell culture life, and work as a quick but significant criteria for developing the optimal conditions for ex vivo MSC multiplication. The appearance of the cells with altered phenotypes serves as an important signal for further decisions considering the fate of culture.

Fibroblastoid morphology and spindle-like shape were confirmed to be a norm and a distinguishing characteristic of MSC [24]. A little is known about the WJ-MSC morphologic behaviour during longterm cultivation, but our data can be compared with those for MSC from other tissue sources.

It was demonstrated that MSC of smaller size, having "classic" slender spindle-like shape usually possess a higher proliferative potential. On the contrary, the proliferative capacity is lower in the cultures that include a lot of cells with flattened shape. This finding allows viewing such morphological peculiarities as a mark of culture senescence [6-10].

The process of MSC aging is complex. In vitro, it depends on many factors and can be exhibited in different ways. The cultures can undergo both "classic" replicative senescence, and premature, stress-induced senescence. However, regardless of the reason, senescence is usually associated with morphologic changes: the appearance of enlarged cells with irregular flattened shape, with many inclusions and vacuoles in cytoplasm. Some researchers note the formation of debris [7].

Various studies demonstrated different terms of appearance of morphological senescence-associated changes. Some researchers described an in vitro MSC cultivation for more than 10 passages without any sign of aging. Others noted a large number of senescent cells already at passage 7 [25]. Such diversity obviously depends on the tissue source of MSC, individual donor features [25-27] the cultivation protocol applied, as well as other factors not revealed yet. When varying the initial plating density, the difference in pace of senescence can be observed even for the cells from the same source.

The present study was focused on the events at early passages. The calculation of NCR and "width/ length" ratio revealed that, even when, visually, the examined cultures shared a high level of similarity, it was possible to detect the differences using the morphometric analysis. The enlarged cells which have flattened shape (though without noticeable presence of granules and vacuoles in cytoplasm), reflecting typical senescent morphology, were observed in significant amounts at the passage 3. This correlated with the drop of proliferation rate demonstrated in our previous works [20]. Notably, plating density used in the present study can be considered as relatively low $[28,29]$. Therefore, the cultures underwent several population doublings within the term of maintenance at each passage.

The interesting effects were observed in MSC, cultivated in the conditions of mild hypoxia, under $3 \%$ of oxygen, in the nitrogen- and argon-based mixtures. In general, the overall number of cells with altered morphology, predominantly the ones with a broad flattened shape, at the passage 3 was lower in gas mixtures, than in $\mathrm{CO}_{2}$-incubator. Furthermore, in gas mixtures the cultures underwent more population doublings (PD), comparing to the control group under standard conditions $[20,30]$. The work by Ren et al. [31] describes the prominent senescence-associated morphologic changes in the cultures under mild hypoxic conditions. This effect is suggested to be connected with a larger number of PD. In the present work, the WJ-MSC cultures with the highest multiplication rates were the most homogenous by size, shape and NCR, resembling the ones from the earliest stages of in vitro maintenance. Such benefi- 
cial effect was most pronounced in the nitrogenbased gas mixture. Our results, thus, are in line with the known data from literature that showed the positive impact of physiological oxygen tensions on the MSC cultures [32].

When working with the MSC cultures, it is necessary to take into account the changes in the heterogeneity level during the whole cultivation period. The present study also revealed a few interesting peculiarities of morphological behaviour of the MSC cultures.

First, WJ-MSC displayed a certain morphological heterogeneity at the passage 0 , and at the passage 1 , its level remained surprisingly high. The fact of morphological homogenization at the passage 2 was an interesting finding. Notably, this effect could not been revealed by visual observation, it became obvious only after morphometric calculations. In our previous study, the passage 2 appeared to be a "threshold" one: from the passage 2, the proliferative potential of cultures dropped [20]. No similar effect is described in the available scientific literature. However, the work by Angelucci et al. [33] has shown that a spectrum of proteins is not expressed after the passage 2 . Considering this, the question of a hypothetical "threshold" passage remains unclear.

Next, it was demonstrated, that the level of heterogeneity in the cultures, maintained under physiological oxygen tensions, was lower, than under the standard $\mathrm{CO}_{2}$-incubator conditions. This concerns both NCR and "width/length" ratio. Many works had reported the correlation between a cell shape and its proliferative capacity. In this context, concerning the data about a higher level of the WJ-MSC multiplication rate under $3 \%$ of $\mathrm{O}_{2}$, demonstrated in our previous works, we suggest that the preservation of such morphological type can reflect the preservation of other MSC-specific features.

It is essential to note that the effects of gas mixtures differed obviously. The morphological homogenization in the MSC cultures maintained in the nitrogen-based gas mixture was more pronounced. The prominent cytoprotective effects of inert gases are described in some publications [34]. In the present study, the cultivation of WJ-MSC in the argon- based gas mixture with $3 \%$ of $\mathrm{O}_{2}$ also had a positive impact on both the culture multiplication and the preservation of morphological type characteristic of initial passages, comparing to the $\mathrm{CO}_{2}$-incubator conditions. However, an enhancing effect in the nitrogen-based mixture was more pronounced. The underlying mechanisms of such effect need to be further investigated.

\section{Conclusions}

During in vitro maintenance of WJ-MSC, the changes in their morphology are observed at early passages. The evidence of senescence can be noted at the passage 3 . The conditions of physiological oxygen tensions had a positive impact on preservation of the cell properties.

The level of morphological heterogeneity in the WJ-MSC cultures varied during a cultivation period. The values of NCR and "width/length" ratio appeared to be most homogenous at the passage 2 . The level of morphological heterogeneity was lower in the cultures, maintained under $3 \%$ of oxygen, comparing to the ones under ambient oxygen concentration.

The biological effects in various gas mixtures were found to be significantly different. The morphology of WJ-MSC, cultured in nitrogen-based mixtures, was the most homogenous in both shape and NCR values.

\section{REFERENCES}

1. Fong CY, Richards M, Manasi N, Biswas A, Bongso A. Comparative growth behaviour and characterization of stem cells from human Wharton's jelly. Reprod Biomed Online. 2007;15(6):708-18.

2. Hsieh JY, Wang HW, Chang SJ, Liao KH, Lee IH, Lin WS, $W u$ CH, Lin WY, Cheng SM. Mesenchymal stem cells from human umbilical cord express preferentially secreted factors related to neuroprotection, neurogenesis, and angiogenesis. PLoS One. 2013;8(8):e72604.

3. Troyer $D L$, Weiss $M L$. Wharton's jelly-derived cells are a primitive stromal cell population. Stem Cells. 2008;26(3): 591-9.

4. Saskianti T, Misami K, Kato Y. Comparison of Hyclone and Biowest: effect to hMSC proliferation, morphology, and osteogenic differentiation. J Trop Life Sci. 2013; 3(1):63-8.

5. Dominici M, Le Blanc K, Mueller I, Slaper-Cortenbach I, Marini F, Krause D, Deans R, Keating A, Prockop Dj, Hor- 
witz E. Minimal criteria for defining multipotent mesenchymal stromal cells. The International Society for Cellular Therapy position statement. Cytotherapy. 2006;8(4):315-7.

6. Katsube Y, Hirose M, Nakamura C, Ohgushi H. Correlation between proliferative activity and cellular thickness of human mesenchymal stem cells. Biochem Biophys Res Commun. 2008;368(2):256-60.

7. Wagner W, Horn P, Castoldi M, Diehlmann A, Bork S, Saffrich R, Benes V, Blake J, Pfister S, Eckstein V, Ho AD. Replicative senescence of mesenchymal stem cells: a continuous and organized process. PLoS One. 2008;3(5):e2213.

8. Digirolamo CM, Stokes D, Colter D, Phinney DG, Class $R$, Prockop DJ. Propagation and senescence of human marrow stromal cells in culture: a simple colony-forming assay identifies samples with the greatest potential to propagate and differentiate. Br J Haematol. 1999;107(2):275-81.

9. Schellenberg A, Lin Q, Schüler H, Koch CM, Joussen S, Denecke B, Walenda G, Pallua N, Suschek CV, Zenke M, Wagner $W$. Replicative senescence of mesenchymal stem cells causes DNA-methylation changes which correlate with repressive histone marks. Aging (Albany NY). 2011; 3(9):873-88.

10. Severino V, Alessio N, Farina A, Sandomenico A, Cipollaro $M$, Peluso $G$, Galderisi $U$, Chambery $A$. Insulin-like growth factor binding proteins 4 and 7 released by senescent cells promote premature senescence in mesenchymal stem cells. Cell Death Dis. 2013;4:e911.

11. Kuhn NZ, Tuan RS. Regulation of stemness and stem cell niche of mesenchymal stem cells: implications in tumorigenesis and metastasis. J Cell Physiol. 2010;222(2):268-77.

12. Kolf CM, Cho E, Tuan RS. Mesenchymal stromal cells. Biology of adult mesenchymal stem cells: regulation of niche, self-renewal and differentiation. Arthritis Res Ther. 2007; 9(1):204

13. Watt FM, Hogan BL. Out of Eden: stem cells and their niches. Science. 2000;287(5457):1427-30.

14. Bork S, Pfister S, Witt H, Horn P, Korn B, Ho AD, Wagner $W$. DNA methylation pattern changes upon long-term culture and aging of human mesenchymal stromal cells. $A g-$ ing Cell. 2010;9(1):54-63.

15. Choo KB, Tai L, Hymavathee KS, Wong CY, Nguyen PN, Huang CJ, Cheong SK, Kamarul T. Oxidative stress-induced premature senescence in Wharton's jelly-derived mesenchymal stem cells. Int J Med Sci. 2014;11(11):1201-7.

16. Wang Y, Zhang Z, Chi Y, Zhang Q, Xu F, Yang Z, Meng L, Yang S, Yan S, Mao A, Zhang J, Yang Y, Wang S, Cui J, Liang L, Ji Y, Han ZB, Fang X, Han ZC. Long-term cultured mesenchymal stem cells frequently develop genomic mutations but do not undergo malignant transformation. Cell Death Dis. 2013;4:e950.

17. Basciano L, Nemos C, Foliguet B, de Isla N, de Carvalho $M$, Tran N, Dalloul A. Long term culture of mesenchymal stem cells in hypoxia promotes a genetic program maintain- ing their undifferentiated and multipotent status. BMC Cell Biol. 2011;12:12.

18. Rosová I, Dao M, Capoccia B, Link D, Nolta JA. Hypoxic preconditioning results in increased motility and improved therapeutic potential of human mesenchymal stem cells. Stem Cells. 2008;26(8):2173-82.

19. Dos Santos F, Andrade PZ, Boura JS, Abecasis MM, da Silva CL, Cabral JM. Ex vivo expansion of human mesenchymal stem cells: a more effective cell proliferation kinetics and metabolism under hypoxia. J Cell Physiol. 2010; 223(1):27-35.

20. Shuvalova NS, Kordium VA. Comparison of proliferative activity of Wharton jelly mesenchymal stem cells in cultures under various gas conditions. Biopolym Cell. 2015; 31(3):233-9.

21. * Культура животных клеток. Методы: Пер.с англ.. Под ред. Р. Фрешни. М.: Мир, 1989. - 333p.

22. McBeath R, Pirone DM, Nelson CM, Bhadriraju K, Chen CS. Cell shape, cytoskeletal tension, and RhoA regulate stem cell lineage commitment. Dev Cell. 2004;6(4):483-95.

23. Kilian KA, Bugarija B, Lahn BT, Mrksich M. Geometric cues for directing the differentiation of mesenchymal stem cells. Proc Natl Acad Sci U S A. 2010;107(11):4872-7.

24. Wang HS, Hung SC, Peng ST, Huang CC, Wei HM, Guo YJ, $F u$ YS, Lai MC, Chen CC. Mesenchymal stem cells in the Wharton's jelly of the human umbilical cord. Stem Cells. 2004;22(7):1330-7.

25. Kern S, Eichler H, Stoeve J, Klüter H, Bieback K. Comparative analysis of mesenchymal stem cells from bone marrow, umbilical cord blood, or adipose tissue. Stem Cells. 2006; 24(5):1294-301.

26. Stenderup K, Justesen J, Clausen C, Kassem M. Aging is associated with decreased maximal life span and accelerated senescence of bone marrow stromal cells. Bone. 2003;33(6):919-26.

27. Bonab MM, Alimoghaddam K, Talebian F, Ghaffari SH, Ghavamzadeh A, Nikbin B. Aging of mesenchymal stem cell in vitro. BMC Cell Biol. 2006;7:14.

28. Carrancio S, López-Holgado N, Sánchez-Guijo FM, Villarón E, Barbado V, Tabera S, Díez-Campelo M, Blanco J, San Miguel JF, Del Cañizo MC. Optimization of mesenchymal stem cell expansion procedures by cell separation and culture conditions modification. Exp Hematol. 2008;36(8): 1014-21.

29. Krinner A, Zscharnack M, Bader A, Drasdo D, Galle J. Impact of oxygen environment on mesenchymal stem cell expansion and chondrogenic differentiation. Cell Prolif. 2009; 42(4):471-84.

30. Shuvalova NS, Kordium VA. Proliferation of Wharton jelly mesenchymal stem cells, derived by preserving the cells with reduced attachment rate, under various gas conditions. Biopolym Cell. 2015; 31(6):447-54.

31. Ren H, Cao Y, Zhao Q, Li J, Zhou C, Liao L, Jia M, Zhao Q, Cai H, Han ZC, Yang R, Chen G, Zhao RC. Proliferation 
and differentiation of bone marrow stromal cells under hypoxic conditions. Biochem Biophys Res Commun. 2006; 347(1):12-21.

32. Fehrer C, Brunauer $R$, Laschober $G$, Unterluggauer $H$, Reitinger $S$, Kloss F, Gülly C, Gassner R, Lepperdinger $G$. Reduced oxygen tension attenuates differentiation capacity of human mesenchymal stem cells and prolongs their lifespan. Aging Cell. 2007;6(6):745-57.

33. Angelucci $S$, Marchisio M, Di Giuseppe F, Pierdomenico L, Sulpizio M, Eleuterio E, Lanuti P, Sabatino G, Miscia S, Di Ilio C. Proteome analysis of human Wharton's jelly cells during in vitro expansion. Proteome Sci. 2010;8:18.

34. Loetscher PD, Rossaint J, Rossaint R, Weis J, Fries M, Fahlenkamp A, Ryang YM, Grottke O, Coburn M. Argon: neuroprotection in in vitro models of cerebral ischemia and traumatic brain injury. Crit Care. 2009;13(6):R206.

\section{Морфологічні характеристики мезенхімальних стовбурових клітин Вартонова студня, що культивовані при фізіологічних концентраціях кисню у різних газових сумішах}

Н. С. Шувалова, В. А. Кордюм

Мета: Культивування мезенхімальних ствобурових клітин (МСК) за знижених концентрацій кисню має сприятливий вплив на їх властивості. Метою даної роботи було дослідити вплив умов помірної гіпоксії на особливості морфології культур МСК Вартонова студня (МСК-ВС) людини. Методи: МСК-ВС були отримані методом експлантів і культивовані в газових сумішах, що містили $3 \% \mathrm{O}_{2}, 4 \% \mathrm{CO}_{2}$ i $93 \%$ азоту або аргону. На кожному пасажі культури було фіксовано та забарвлено гематоксиліном і еозином. За допомогою морфометрії визначали ядерно-цитоплазматичне співвідношення (ЯЦС) і коефіцієнт «ширина/довжина», який розраховували як відношення ширини клітини до іiі довжини. Результати: Різницю по ЯЦС і коефіцієнту «ширина/довжина» було виявлено як між культурами МСК на різних пасажах, так між культурами одного пасажу 3 різних газових сумішей. Найвищий рівень морфологічної гомогенності можна було спостерігати на другому пасажі. На третьому пасажі почали 3'являтись клітини, що мали старіючий фенотип. Рівень морфологічної гетерогенності в популяціях, культивованих за $3 \% \mathrm{O}_{2}$, був нижчим, ніж в умовах $\mathrm{CO}_{2}$-інкубатора (атмосферна концентрація кисню $\approx 20 \%$, вуглекислий газ $-4 \%$ ). Найбільш гомогенними були МСК, культивовані в суміші на основі азоту. Висновки: У процесі культивування МСК-ВС на ранніх пасажах спостерігаються зміни морфології по ЯЦС и формі клітин. У процесі культивування рівень морфологічної гетерогенності в культурах змінювався. Умови фізіологічних концентрацій кисню мали позитивний вплив на культивовані клітини.

Кл юч о в і с л о в а: мезенхимальні стовбурові клітини, Вартонів студень, гіпоксія, морфологія, аргон

\section{Морфологические характеристики мезенхимальных стволовых клеток вартонова студня, культивируемых при физиологических концентрациях кислорода в различных газовых смесях}

Н. С. Шувалова, В. А. Кордюм

Цель: Культивирование мезенхимальных стволовых клеток (МСК) при пониженных концентрациях кислорода благоприятно влияет на многие их свойства. Задачей данной работы было исследовать влияние условий умеренной гипоксии на особенности морфологии культур МСК Вартонова студня (МСК-ВС) человека. Методы: МСК-ВС были получены методом эксплантов и культивированы в газовых смесях, содержащих $3 \% \mathrm{O}_{2}, 4 \% \mathrm{CO}_{2}$ и $93 \%$ азота либо аргона. На каждом пассаже культуры фиксировали и окрашивали гематоксилином и эозином. С помощью морфометрии определяли ядерно-цитоплазматическое соотношение (ЯЦС) и коэффициент «ширина/длинна», который рассчитывали как отношение ширины клетки кеё длине. Результаты: Различия по ЯЦС и коэффициенту «ширина/длинна» были обнаружены как между культурами МСК на разных пассажах, так и между культурами одного пассажа из разных газовых смесей. Самый высокий уровень морфологической гомогенности можно было наблюдать на втором пассаже. На третьем пассаже стали появляться клетки со стареющим фенотипом. Уровень морфологической гетерогенности в популяциях, культивированных при $3 \% \mathrm{O}_{2}$, был ниже, чем в условиях $\mathrm{CO}_{2}$-инкубатора (атмосферная концентрация кислорода, $\approx 20 \%$, углекислый газ - 4 \%). Самыми гомогенными были МСК, культивированные в смеси на основе азота. Выводы: В процессе культивирования МСК-ВС на ранних пассажах наблюдается изменение морфологии по ЯЦС и форме клеток. В процессе культивирования уровень морфологической гетерогенности в культурах изменялся. Условия физиологических концентраций кислорода, позитивно влияли на культивированные клетки.

Ключевы е слова: мезенхимальные стволовые клетки, Вартонов студень, гипоксия, морфология, аргон

Received 03.06.2016 